\title{
The Production of Bioethanol from Corncob as Fuel for Generator Set of Gasoline Motor
}

\author{
$1^{\text {st }}$ Christian Asri Wicaksana \\ Department of Mechanical Engineering \\ Universitas Negeri Malang \\ christianaksa94@gmail.com \\ Malang, Indonesia
}

\author{
$2^{\text {nd }}$ Muhammad Alfian Mizar \\ Department of Mechanical Engineering \\ Universitas Negeri Malang \\ Malang, Indonesia \\ alfianmizar@gmail.com
}

\author{
$3^{\text {rd }}$ Widiy anti \\ Department of Mechanical Engineering \\ Universitas Negeri Malang \\ Malang, Indonesia \\ Widiy anti.ft @um.ac.
}

\begin{abstract}
Along with the development of the era and the technology, which are rapidly growing every time, the global communities receive both positive and negative impacts from these advancements. One of the negative effects is the issue of waste. Physically, there are three types of waste: solid, liquid, and gas. In general, organic waste is contributing the most to the amount of waste currently. One of the examples of solid waste, which comes from the agricultural process, is corncob. Corncob is often only used for animal feed or as a substitute for firewood in the absence of further treatment. These simple utilization of corncob, decrease either value of its usability or its economic value. One of the efforts to improve the usability and economic value of corncob is by processing it into bioenergy, such as bioethanol. The purpose of this study is to explore the bioethanol production process from corncob and to find out the level of purity of the ethanol, which is resulted from the same bioethanol production process. This study employed experimental as its design. The results expose that corncob can be used as the raw material for producing bioethanol which underwent several processes; pretreatment, hydrolysis for a day, fermentation for seven days, and four times of distillation process with the temperature of $52-72,5^{\circ} \mathrm{C}$ and the pressure of $95,5-107,3$ mBar, which produce ethanol of $96 \%$.
\end{abstract}

Keywords-alternative energy; bioethanol from corncob; fuel for generator set

In this modern era, the problem of waste management has become a significant global issue. This issue is mainly caused by the increasing amount of the waste, but there has not been an effort to degrade the adverse effect of the waste Physically, the waste consists of three types; they are gases, liquids, and solids. The biggest contributor to the waste type produced in urban areas is the organic wastes which approximately reach the amount of $65 \%^{[1]}$. One of the types of organic solid waste which have not been exploited to its full potential is the waste of agricultural output in the form of corncob. Corncob is one of the inner parts of the female organ. Commonly, corncob is utilized as livestock feed. Thus, it possesses low consumption and economic value. The utilization of corncob waste can be carried out with the method of bioconversion, which emphasizes the transformation of the waste into fuel by involving microorganisms in the manufacturing process. During 1969 - 2015, the highest peak of corn production in Indonesia was reached by 2015 with the results of 20.667 million tons ${ }^{[2]}$.

The current primary energy consumption of the community consists of $3.11 \%$ of water power, $1.32 \%$ of geothermal, $51.66 \%$ of petroleum, $15.34 \%$ of coal and $28.57 \%$ of gas ${ }^{[3]}$. The estimated numbers of world energy consumption will increase by as much as $57 \%$ from 2002 to $2025^{[4]}$ which where an increasing number of greatest consumption occurred in the various areas within developing countries, such as Indonesia. Bioethanol is one of the biofuels which never get expired as long as the Sun is shining, the water is available, the need for oxygen is fulfilled, and the existence of agriculture cultivation ${ }^{[5]}$. Bioethanol has several advantages when compared to conventional fuel oil, i.e. has a higher oxygen content $(35 \%)$ so that the burning is more perfect, higher octane value (118) and more environmentally friendly because it contains lower levels of CO $19-25 \%$ [6]. Therefore, bioethanol is the most recommended alternative energy, which is renewable and it can handle the pollution issues ${ }^{[7]}$. The involved raw 
materials to produce bioethanol is molasses ${ }^{[8]}$ as well as some ingredients with rough fiber and high carbohydrate content ${ }^{[9]}$.

Ethanol can be used in its pure form, the fuel mixture petrol (gasoline), as well as the interaction of ethanol with the energy source which produces hydrogen fuel cell for an internal combustion engine. The plant which is potential to be used as raw material for producing bioethanol is the plant which possess high levels of carbohydrates, such as sugar cane, molasses, areca palm, sorghum, cassava, cashew (cashew waste), arrowroot, banana tree, sweet potato, corn, of corn, hay, and bagas (sugar cane husks). ${ }^{[10]}$. Ethanol has several characteristics; is in liquid form (a liquid substance), flammable, odorless, colorless, can be mixed with water with a variety of comparisons, and easily vaporized ${ }^{[11]}$.

In its simple way, the process of making bioethanol begins with the pretreatment on raw materials to broaden cross-sectional surfaces of the raw materials at a time when the creation process is done by way of making raw material size is smaller. After that, move to the next step which is the process of hydrolysis. The goal of this process is to transform the starch or polysaccharide contained in raw materials into elements of glucose which are chemically simpler, and this process is done with the help of certain substances with certain enzymes or $\mathrm{pH}$. After that, the result of hydrolysis is reacted with certain microbes to be fermented for several days. This stage processes the decomposition of glucose into alcohol (ethanol) and carbon dioxide $\left(\mathrm{CO}_{2}\right)$. The fermentation process is done anaerobically. After the process fermentation is complete, then, the fermented liquid is taken to be purified, so the pure ethanol is obtained in certain levels with the absence of a mixture of water with the help of instruments made by distillation temperature evaporation of ethanol, i.e. about $78.4^{0} \mathrm{C}^{[12]}$.

The purposes of this study are to explore the process of making bioethanol from corncob and find out the level purity of the ethanol which produced from the process of making bioethanol from corncob.

\section{RESEARCH METHOD}

This research employed experimental research design. The experimental research method is defined as a research method which can be used to search for the specific treatment of the influence given to the others in the condition that can be controlled ${ }^{[13]}$.

\section{A. Instruments and Materials}

The use of the tools in this study is useful to help the process of collecting data from the testing which would be done to make it easier and the results obtained would be more accurate, meticulous and systematic, complete, so it is easy to be processed. The employed test tool to support this study was the evaporator machine for bioethanol process. The measuring instruments used in this research were analog and mass scales, alcoholmeter, measuring cup, and the Erlenmeyer flask. The ingredients involved in this research were the corncob, water, the Saccharomyces cerevisiae microbe within the yeast bread

\section{1) Data Collection}

These are the stages or phases of the process of making bioethanol from corncob:

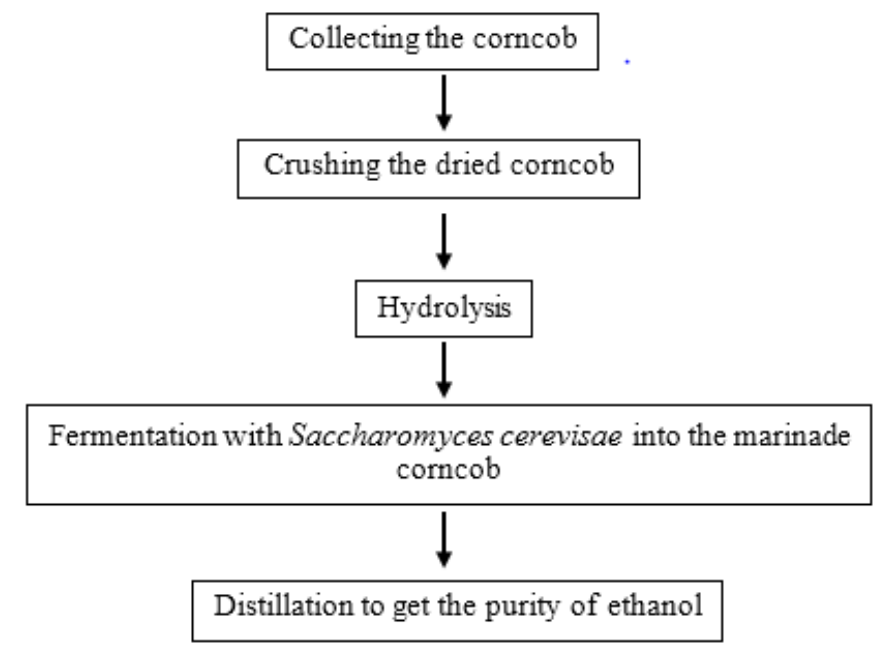

Fig 1. The phase in making bioethanolfrom corncob

\section{2) Data Analysis}

This study employed descriptive analysis method in order to explain the process and the result of distillation from the process of producing bioethanol from corncob. 


\section{RESULTS}

\section{A. The Process of Producing Bioethanol from}

\section{Corncob}

In the early stages of making bioethanol from corncob, the process of pretreatment was conducted by way of drying out the corncob and crushing them into pieces. The dried corncob used for testing were as much as $3.5 \mathrm{~kg}$.

Furthermore, the process of hydrolysis is done by soaking the pieces of corncob with water as much as $20 \mathrm{~L}$ in a sealed container for a day.

At the third stage, the process of fermentation with Saccharomyces cerevisae, which found in yeast bread, as many as 60 gr into the marinade corncob. The anaerobic fermentation process was carried out for seven days.

The last process of producing bioethanol from corncob was distillation. Prior to the distillation process, the fermented liquid of bioethanol from corncob was filtered beforehand with the purpose to remove the dirt.

\section{B. Distillation Test Results from Corncob Bioethanol}

The process to get the level of purity of ethanol $(\%)$ at this stage required four times the distillation process by using the help of evaporator engine. The following results show the refining of bioethanol liquid fermentation from corncob:

T ABLE 1. Distillation TEST RESUlTS

\begin{tabular}{ccccccc}
\hline No. & Distillations & Temperature & Pressure & $\begin{array}{c}\text { Flask } \\
\text { Bottle } \\
\text { Rotation }\end{array}$ & $\begin{array}{c}\text { Results } \\
\text { (Volume) }\end{array}$ & $\begin{array}{c}\text { Level } \\
\text { Purity of } \\
\text { Ethanol }\end{array}$ \\
\hline 1. & First & $52^{\circ} \mathrm{C}$ & $107,3 \mathrm{mBar}$ & $65 \mathrm{Rpm}$ & $6,4 \mathrm{~L}$ & $60 \%$ \\
2. & Second & $64,3^{\circ} \mathrm{C}$ & $101,2 \mathrm{mBar}$ & $67 \mathrm{Rpm}$ & $5,8 \mathrm{~L}$ & $74 \%$ \\
3. & Third & $68,5^{\circ} \mathrm{C}$ & $98 \mathrm{mBar}$ & $66 \mathrm{Rpm}$ & $4,6 \mathrm{~L}$ & $83 \%$ \\
4. & Fourth & $72,5^{\circ} \mathrm{C}$ & $95,5 \mathrm{mBar}$ & $66 \mathrm{Rpm}$ & $3,2 \mathrm{~L}$ & $96 \%$ \\
\hline
\end{tabular}

\section{DISCUSSION}

\section{A. The Process of Manufacturing Bioethanol from Corncob}

The pretreatment process was done by drying out the corncob with the aim to eliminate the moisture contained in it and to be able to calculate the weight of corncob used without any mixture of other substances which can change the characteristics of the corncob. In addition the process of pulverizing the corncob was done with the purpose to expand the absorption are of the corncob during the next process for producing bioethanol.

The hydrolysis process was done with water for the purpose of using substances which are easily obtained and can be employed for hydrolysis. The volume of water used was adjusted by the number of parts of dried corncob which were used.

The determination of the composition from the yeast bread, as much as 60 gr, and the number of days used for the fermentation process, which was seven days, was based on the field trials which have been conducted independently.

The process of distillation was performed four times in order to obtain the most optimum level of purity of ethanol from fermented corncob. The working principle of the process of distillation is to evaporate the ethanol contained in the fermented liquid of corncob and to re-condense it.

\section{B. Distillation Test Results from Corncob Bioethanol}

Based on table 1. Is known that for every repetition of the process of distillation with the evaporator machine, some obtained facts show that the temperature which will be used will increase and the pressure will decrease. It is possible to happen because in the early stages of purification there were other substances besides ethanol within the fermented liquid from corncob. Thus, in order to evaporate the ethanol, a low temperature heat was still used.

The next repetition process carried out the process of increasing the temperature of the evaporator machine, so it almost reached the ethanol's boiling peak, which is $78.4^{0} \mathrm{C}$ so that the results obtained were pure ethanol and for a given pressure dropped on each repetition of the process of distillation was done to keep the flask used as a container of fermented liquid away from breaking apart. In addition, the working principle of this evaporator machine is: when the temperature is raised then the given pressure is inversely proportional, which is lowered.

As for the amount of liquid which obtained will also decline, but the level of purity of ethanol will increase. It is because that the fermented liquid 
contains other substances in addition to ethanol, thus, when the only evaporated substance was the ethanol, then the number of volumes of the pure ethanol-containing liquid is reduced but the level of purity is increased.

\section{CONCLUSIONS}

Based on the results of research and discussion which have been parsed, then several conclusions were obtained:

1. Corncob can be used as an alternative to making the bioethanol which is used as a motor gasoline fuel. Through the process of initial pretreatment, the process of hydrolys is with water for one day, the phase of fermentation by using the bacteria $S$. cerevisiae for seven days, and finally, the distillation process as much as four times with temperatures between $52-72,5^{\circ} \mathrm{C}$ by involving a pressure between $95.5-$ 107.3 mBar.

2. Through the process of distillation, as much as four times by involving evaporator machine will obtain $96 \%$ bioethanol in an amount of $3.2 \mathrm{~L}$.

\section{REFERENCES}

[1] Irawan, D. dan Arifin, Z. 2010. Pemanfaatan Sampah Organik Kota Samarinda menjadi Bioetanol: Klasifikasi dan Potensi. Artikel disajikan dalam Seminar Rekayasa Kimia dan Proses, Jurusan Teknik Kimia, Universitas Diponegoro, Semarang, 2010.

[2] Kementerian Pertanian. 2015. Outlook Komoditas Pertanian Tanaman Pangan Jagung. Jakarta: Pusat Data dan Sistem Informasi Pertanian Kementerian Pertanian.
[3] Jos, B. 2010. Peran Teknologi Separasi dalam Pengembangan Energi Terbarukan. Pidato Pengukuhan. Semarang: Badan Penerbit Universitas Diponegoro.

[4] Walisiewicz, M. Tanpa Tahun. Energi Alternatif: Paduan ke Masa Depan Teknologi Energi. Terjemahan Dwi Setya. 2003. Jakarta: Erlangga.

[5] Yanuar, B dan Amrullah, A. 2015. Uji Eksperimental Bioetanol Eceng Gondok Hasil Destilasi dengan Variasi Waktu Fermentasi. Artikel disajikan dalam Seminar Nasional Tahunan Teknik Mesin XIV (SNTTM SIV), Banjarmasin, 7-8 Oktober 2015.

[6] Indartono, Y. 2005. Bioetanol, Alternatif Energi Terbarukan: Kajian Prestasi Mesin dan Implementasi di Lapangan. LIPI.

[7] Wang, F. et al. 2016. An Environmentally Friendly and Productive Process for Bioethanol Production from WastePotato. Biotechnology for Biofuels, 9 (50): 1-10.

[8] Kusmiyati dan Arifin, A. N. 2010. Konversi Umbi Iles-Iles menjadi Bioetanol dengan Metode Konvensional dan SSF (Sakarifikasi dan Fermentasi secara Serentak). Artikel disajikan dalam Simposium Nasional RAPI IX, Jurusan Teknik Kimia, Universitas Muhammadiyah Surakarta, Surakarta, 2010.

[9] Permana, D. R. dan Prasetya, B. 2014. Bioetanol dari Limbah Jamur Tiram (Pleurotus ostreatus, Jacq.Fr.) sebagai Energi Alternatif Terbarukan. Artikel disajikan dalam Seminar Nasional Sinergi Pangan Pakan dan Energi Terbarukan, Pusat Penelitian Bioteknologi, LIPI, Yogyakarta, 21 - 23 Oktober 2014.

[10] Kurniawan, A. D., Semin, dan Suprajitno, T. 2014. Analisa Penggunaan Bahan Bakar Bioethanol dari Batang Padi sebagai Campuran Pada Bensin. Jurnal Teknik POMITS, 2 (1): 1-5.

[11] Muslihah, S. 2012. Pengaruh Penambahan Urea dan Lama Fermentasi yang Berbeda terhadap Kadar Bioetanol dari Sampah Organik. Skripsi tidak diterbitkan. Malang: UIN Maulana Malik Ibrahim.

[12] Yonas, M. I. 2013.Pembuatan Bioetanol Berbasis Sampah Organik Batang Jagung (Suatu Penelitian di Laboratorium Kimia UNG). Skripsi tidak diterbitkan. Gorontalo: Universitas Negeri Gorontalo.

[13] Sugiyono. 2010. Metode Penelitian Kuantitatif, Kualitatif, dan R\&D. Bandung: Alfabeta Bandung. 